\title{
CFD simulation of train aerodynamics: train-induced wind conditions at an underground railroad passenger platform
}

\author{
Adelya Khayrullina ${ }^{1)}$, Bert Blocken* ${ }^{1,2)}$, Wendy Janssen ${ }^{1)}$, Jochem Straathof ${ }^{1)}$ \\ 1) Building Physics and Services, Department of the Built Environment, Eindhoven University \\ of Technology, P.O. box 513, 5600 MB, Eindhoven, the Netherlands \\ 2) Building Physics Section, Department of Civil Engineering, Leuven University, Kasteelpark \\ Arenberg 40 - bus 2447, 3001 Leuven, Belgium \\ *) Corresponding author: Bert Blocken, Building Physics and Services, Eindhoven University \\ of Technology, P.O. box 513, 5600 MB, Eindhoven, the Netherlands \\ Tel. +31 (0)40 247 2138, Fax: +31 (0)40 243 8595, e-mail: b.j.e.blocken@tue.nl
}

\section{Graphical abstract}

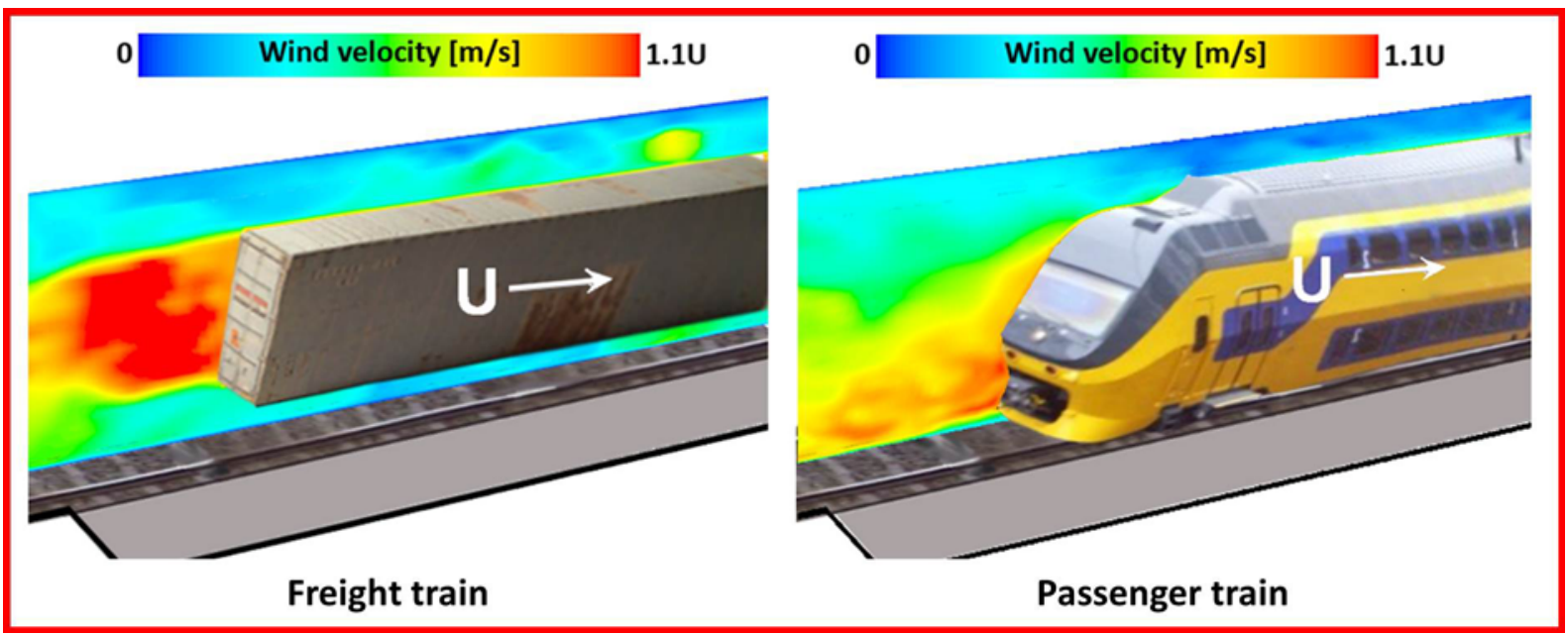

\section{Highlights}

- Trains running through a tunnel can induce high wind speed at underground railroad platforms

- This paper presents Large Eddy Simulations of train-induced wind conditions for three different train types

- The study includes grid-sensitivity analysis and validation based on experimental data

- The study is performed with the sliding mesh method for relative motion between train and tunnel

- It shows that the expansion wave generally causes stronger wind gusts than compression wave 


\begin{abstract}
The Dutch railways plan to increase the amount of trains and their running velocities to avoid overcrowded trains during rush hours. This can cause pedestrian wind discomfort or danger at the platforms as trains will be allowed to pass small railway stations at high speeds up to $140 \mathrm{~km} / \mathrm{h}$. A number of these railway stations lie underground, where wind gusts caused by trains are amplified by space confinement. The purpose of this study is to evaluate the effect of passing passenger trains and freight trains on the wind conditions induced on a passenger platform inside an underground tunnel by means of Large-Eddy simulations (LES). First, the computational model, which includes stationary (tunnel and platform) and moving (train) subdomains, is validated by available experimental data for a train running through a tunnel. Next, case studies are performed for a passenger train and a freight train, where the dimensions of the tunnel and the platform are chosen from the Dutch design requirements for railroad tunnels and platforms. The results of the study show that passengers standing on a platform can experience strong wind effects when passenger trains or freight trains are passing at speeds of 140 and $100 \mathrm{~km} / \mathrm{h}$, respectively. These effects might give rise to wind discomfort or even wind danger, and should be taken into account in the design of railway tunnels and platforms and in safety regulations.
\end{abstract}

Keywords: Train aerodynamics, Computational fluid dynamics (CFD), Sliding mesh, Wind comfort, Wind danger, Tunnel Platform.

\title{
1 Introduction
}

The Dutch railways transport more than $1.2 \times 10^{6}$ passengers a day and $0.6 \times 10^{6}$ passengers during rush hours, resulting daily in more than 5,200 train rides. To avoid overcrowded trains, the amount of passenger trains and freight trains will be augmented and their running velocities will be increased up to $140 \mathrm{~km} / \mathrm{h}$ (ProRail 2014). Trains passing small railway stations at these high speeds might cause pedestrian wind discomfort or wind danger on the platforms.

A number of railway stations lie underground and due to the space confinement this results in increased air movements and augmented velocities in front of and behind the running train (Baker et al. 2012, Gilbert et al. 2013a, 2013b). Air inside a tunnel is confined by the tunnel walls and, therefore, a compression wave is created in front of the moving train, while an expansion wave is created behind the train (Fig. 1). This phenomenon is called the "piston effect".

The piston effect and the resulting pressure waves propagation are described in (William-Louis and Tournier 2005, Novak 2006). The main factors that influence the strength of the pressure waves are the blockage ratio of the train in the tunnel (which is defined as the ratio of the train cross-section to the tunnel cross-section), the shape of the nose and tail of the train, the train velocity, the shape of the tunnel entrance and exit, the tunnel length and the roughness of the train body and the tunnel walls (Baron et al. 2001, Raghunathan et al. 2002, Novak 2006, Ricco et al. 2007, Bopp and Hagenah 2009).

Topics that have been addressed in previous studies on train aerodynamics include:

- train-induced slipstreams in open field (Baker et al. 2006, Sterling et al. 2008) and in confined spaces (Gilbert et al. 2013a, 2013b);

- effect of crosswinds on trains and the risk of a train to fall over while running in open field (Hemida and Baker 2010, Eighinger et al. 2013, Sima and Venkatasalam 2013);

- pressure distribution and variation inside tunnels (Baron et al. 2001, Raghunathan et al. 2002, Ricco et al. 2007, Hieke et al. 2013);

- ballast flying and projection, displacement of ballast stones induced by high speed of a train and damaging train details (Sima et al. 2008, Saussine et al. 2013, Weise and Sima 2013). 
Baker et al. (2006) and Baker (2010) discussed a number of experimental and numerical studies on the assessment of the slipstream gusts caused by passing trains in open field, with and without cross winds. They also described the potential effects of wind gusts on exposed people. They mentioned that there is a large variability in experimental data due to different boundary conditions, train types and complex flow structures induced by a moving train. Three regions around a train moving in open field were distinguished: the nose region, the boundary-layer region, and the wake region. Also, these authors highlighted the development of turbulent gust flows in the near wake for high-speed trains and in the growing boundary layer of freight trains. These unsteady flows can cause discomfort or even destabilize people standing alongside the moving train, by gusts with speed above $15-20 \mathrm{~m} / \mathrm{s}$ (Baker et al. 2006). Sterling et al. (2008) analyzed experimental data for high-speed passenger trains and freight trains in open field. They examined the different flow regimes within the three regions around a train and, in line with the previously discussed studies, highlighted the intermittent behavior of the near wake flows. The velocities were found to be higher in the near wake and the boundary layer regions than in the nose region of the train. They also mentioned that the boundary layer development was slightly different between full-scale and reduced-scale measurements and that this could influence the near wake flow.

Gil et al. (2008) mentioned considerable run-to-run variability in the measured data for a $1 / 25^{\text {th }}$ scale train with 3 carriages moving on a circular track with speeds of about $5 \mathrm{~m} / \mathrm{s}$ to $15 \mathrm{~m} / \mathrm{s}$. They experimentally showed that higher train speeds cause higher ratios of slipstream velocity to train speed. However, Hemida et al. (2010) studied a 1/25 scale model of an ICE train running on a circular track in an open space using validated LES simulations and showed that the Reynolds number effect on normalized slipstream velocities is negligible for trains moving with speeds varying within $20 \%$.

Finally, Hemida et al. (2014) in their LES study investigated the effect of the platform height on the slipstream velocity. The slipstream velocities that occurred with a higher platform were increased due to the blocking of the developing slipstream flow. They also monitored the instantaneous flow in the wake of the train and confirmed the presence of highly turbulent vorticity. The maximum velocities and the largest turbulence intensities were observed in the near wake of the passenger train.

In Wind Engineering, many studies on pedestrian wind conditions were performed in the past decades. By far most of these studies focused on wind around buildings, as outlined in several review papers (Stathopoulos 1997, 2002, 2006, Baker 2007, Mochida and Lun 2008, Blocken et al. 2011, 2012, Moonen et al. 2012, Blocken 2014 ). While early studies on pedestrian wind conditions around buildings were performed in atmospheric boundary layer wind tunnels, the past decade has seen a rapid increase in the use of CFD for this purpose (Blocken 2014). This increase has been supported by the development of extensive sets of best-practice guidelines (Casey and Wintergerste 2000, Franke et al. 2004, 2007, 2011, Britter and Schatzmann 2007, Tominaga et al. 2008, Blocken and Gualtieri 2012). Note however that most CFD studies on pedestrian-level wind comfort and wind danger were performed based on the steady Reynolds-Averaged Navier-Stokes equations, rather than on Large Eddy Simulation (LES) (e.g. Yoshie et al. 2007, Blocken et al. 2014). To the best knowledge of the authors, no studies have yet focused on CFD simulations of train-induced pedestrian wind conditions on platforms inside tunnels.

The purpose of this study is to evaluate the effect of a passing train on the wind flow induced inside a tunnel by means of LES, and assess the wind conditions at an underground railroad passenger platform. First, a validation study is performed, using experimental data of Gilbert et al. (2012) who analyzed train-induced air flow in a confined space and, in line with previous findings, observed occurrence of compression and expansion waves in front of and behind the train, respectively. Next, based on the validation study, simulations are performed for two case studies with two different train types that occur on the Dutch railways. A fictive underground railroad platform is designed according to current national guidelines. The occurring wind velocities on this platform are assessed and compared with threshold values for wind comfort and wind danger for pedestrians. 


\section{Guidelines for railway platforms and wind speed threshold values}

According to ProRail (2012), a platform (underground or above-ground) has to be subdivided into four zones (Fig. 2): (1) a safety zone that should be avoided by people while trains are passing by, (2) a walking zone, (3) a waiting zone, and (4) a circulation zone used for benches and information stands. ProRail does not provide guidelines concerning wind comfort and wind danger. However, we can assume that dangerous gusts are only allowed in the safety zone, where people should not stand. Certainly, dangerous gusts should not occur in the walking zone, the standing/waiting zone and the circulation zone. Discomfortable wind conditions should not occur in the standing/waiting zone and in the circulation zone, where people are sitting and waiting for the train.

A threshold value for wind discomfort is chosen based on the findings that wind speeds of $5 \mathrm{~m} / \mathrm{s}$ and higher can cause wind discomfort for brisk walking, strolling or sitting (Lawson and Penwarden 1975). Also, wind velocities of $2.4-5.5 \mathrm{~m} / \mathrm{s}$ cause hair dissarangement and difficulties with reading the paper and can raise dust and loose paper (Lawson and Penwarden 1975). Therefore, a wind speed of $5 \mathrm{~m} / \mathrm{s}$ is taken as the threshold value for wind discomfort in the present study.

Concerning wind danger, Jordan et al. (2008) showed that people can lose their balance at gusts from $12 \mathrm{~m} / \mathrm{s}$ when the gust wind is coming from the side, as is the case with people standing on the platform and facing the track. In addition, the duration and acceleration of the wind gust should be considered. According to Bottema (1993), the average critical duration of a gust for a female weighing $60 \mathrm{~kg}$ and male weighing $75 \mathrm{~kg}$ standing sideways to the oncoming gust wind of $12 \mathrm{~m} / \mathrm{s}$ is around $0.5 \mathrm{~s}$ before their balance is lost. Finally, De Graaf and Van Weperen (1997) investigated people's tolerance to acceleration by wind depending on the direction of the wind force. They found that a side wind with an acceleration of $0.43 \mathrm{~m} / \mathrm{s}^{2}$ can destabilize a person. The combination of values of gust wind equal to $12 \mathrm{~m} / \mathrm{s}$, its duration of $0.5 \mathrm{~s}$ and acceleration of $0.43 \mathrm{~m} / \mathrm{s}^{2}$ are used as threshold for wind danger in the present study.

\section{Validation study}

\subsection{Experiments}

In the experiments by Gilbert et al. (2012) in the TRAIN Rig at the University of Birmingham, a $1 / 25^{\text {th }}$ scale model of a German ICE-2 train with a model-scale length of $4.24 \mathrm{~m}$ was travelling with a speed of $32 \mathrm{~m} / \mathrm{s}(115 \mathrm{~km} / \mathrm{h})$ through an $8.0 \mathrm{~m}$ (model-scale) long tunnel, where inside wind velocities were measured with a Cobra probe PRB1 and data of 25 train runs were obtained (Fig. 3). This probe was positioned at a model-scale distance of $4.88 \mathrm{~m}$ from the inlet of the tunnel. The blockage ratio (train cross-section to tunnel cross-section) was $30 \%$.

\subsection{Model geometry, grid, boundary conditions and other computational settings}

The simulations are performed at model scale by the commercial CFD code ANSYS Fluent 12.1. The sliding mesh method is adopted to create the relative motion between the train and the tunnel. The computational domain is divided in two subdomains: a stationary subdomain including the tunnel and the underground platform, and a moving subdomain including the train with a volume of air around it (Fig. 4a). Faces in between sliding and stationary subdomains have an interface boundary condition (ANSYS 2009). By that, non-conformal grids of these subdomains can be attached to each other. The air-zone length in front of and behind the train in the moving subdomain is equal to the tunnel length of $8 \mathrm{~m}$, to take into account the pressure gradients created by the train entering and exiting the tunnel. Note that ANSYS creates temporary wall surfaces for the boundaries where two interfaces do not overlap. 
The computational grid for the stationary subdomain (Fig. 4b) is generated using the surface-grid extrusion technique described by van Hooff and Blocken (2010). The grid is finer near the interfaces, close to the train. The stationary subdomain consists of five zones (Fig. 4c): the tunnel zone in the middle and two field zones adjacent to the tunnel zone, where the blockage area of the train is equal to $2 \%$, which is according to best practice guidelines (Franke et al. 2007, Tominaga et al. 2008). The two outer zones represent open field areas, which are needed because interfaces are transformed into walls as soon as they are not connected to each other.

For the computational grid of the moving subdomain, firstly, faces covering the volume of the train are created and meshed (Fig. 4d, 4e). Afterwards, the volume around the train is meshed. Due to the complex geometry of the train, not only hexahedral, but also tetrahedral and prismatic cells are used for the air volume around the train. A velocity of $32 \mathrm{~m} / \mathrm{s}$ is prescribed to the moving subdomain. Note that the grid is chosen based on grid-sensitivity analysis with three grid configurations shown in Figure 5.

The wind velocities at point PRB1 (Fig. 3b) are computed for the three grids (Fig. 6). Results of the middle and fine grids correspond well to each other, while the coarse grid provides markedly different velocities when the nose of the train has passed the measurement point $(\mathrm{t} \sim 0.0 \mathrm{~s})$. Therefore, the middle grid is used in the validation study. For this grid, the number of cells along the tunnel height is 20 and 26 along the tunnel width. The number of cells is $1.2 \cdot 10^{6}$ for the moving subdomain and $0.8 \cdot 10^{6}$ for the stationary subdomain.

A symmetry boundary condition (i.e. zero normal velocity and gradients) is assigned to the lateral and the top boundaries of the field zone, while zero static (gauge) pressure is imposed at the lateral and the top boundaries of the outer zones. The computational settings are summarized in Table 1. The time step is calculated by:

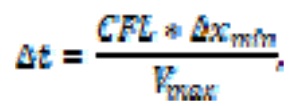

where $\Delta \mathrm{x}_{\min }$ is the smallest length of a cell in the calculation domain (here: $1.1 \cdot 10^{-3} \mathrm{~m}$ ), $\mathrm{V}_{\max }$ is the velocity of the moving subdomain (here: $32 \mathrm{~m} / \mathrm{s}$ ) and CFL is the Courant-Friedrichs-Lewy number, which is typically $\leq 1$. The number of time steps is 12960 , which is needed to provide the complete passage of the train and a part of its computational "air zones" through the tunnel. The train nose is positioned at model-scale distance of $0.4 \mathrm{~m}$ from the entrance of the tunnel at the beginning of simulation.

\subsection{Validation results}

The computed velocities at point PRB1 obtained by ten simulation runs are normalized by the train speed of $32 \mathrm{~m} / \mathrm{s}$ and presented in Figure 7 together with the experimental data of Gilbert et al. (2012). Note that at time $0.0 \mathrm{~s}$ and $3.3 \mathrm{~s}$ the nose and the tail of the train, respectively, reach the measurement point. As illustrated, the peak of the compression wave is not well predicted by the LES simulation. The wind velocity is underestimated just before the train nose passes PRB1 $(\mathrm{t}<0.0 \mathrm{~s})$ and after the tail of the train has passed PRB1 $(\mathrm{t}>3.3 \mathrm{~s})$. However, the values are within one standard deviation of the performed measurements. The large standard deviations are caused by the high fluctuations in measured wind velocities during the 25 experimental runs and the 10 numerical runs.

The differences between experimental and numerical results can be caused by the applied zero roughness (no-slip condition, equivalent sand-grain roughness height $\mathrm{k}_{\mathrm{s}}=0 \mathrm{~m}$ ) for the train and tunnel walls in the numerical simulations, and due to the limitation of the Cobra probe to measure wind velocities only within a $\pm 45^{\circ}$ cone. Difficulties in measuring data with the Cobra probe and its limitation to register only a mainstream flow, but not a complex reverse flow, were mentioned in studies by Gil et al. (2008) and Hemida et al. (2014). Because there is an acceptable agreement 
between the experimental and numerical data, the computational settings of the validation study (Table 1 ; except for time step size and number of time steps) are also applied in the case studies.

\section{Case studies}

\subsection{Geometry of trains, tunnel and platform}

Two trains are selected: (1) a passenger (VIRM ${ }^{1}$ ) train (Fig. 8a) with a length of $107.5 \mathrm{~m}$ and (2) a freight train (Fig. 8b) with a length of $105.2 \mathrm{~m}$. The trains separately run through a tunnel with a length of $250 \mathrm{~m}$ (Fig. 9) and pass a platform with a length of $150 \mathrm{~m}$ at a speed of $38.9 \mathrm{~m} / \mathrm{s}(140 \mathrm{~km} / \mathrm{h})$ and $27.8 \mathrm{~m} / \mathrm{s}(100 \mathrm{~km} / \mathrm{h})$, respectively. Note that a freight train consists of one TRAXX 2803 locomotive that carries six rectangular container carriages, which are assumed to be fully loaded (Fig. $8 \mathrm{~b}$ ). The distance (gap) between each two carriages, which is included in the model, is $1.3 \mathrm{~m}$, while for the passenger train, the distance between each two carriages is only $0.4 \mathrm{~m}$ and is covered by a flexible connector, aerodynamically reducing the gap size to zero. For this reason, the latter gaps are not included in the model and the whole passenger train is modeled as a continuous solid volume. The blockage ratio of the train in the tunnel is $39 \%$ and $36 \%$ for the passenger and freight train, respectively.

The dimensions of the tunnel and the platform are chosen according to the design guidelines of the Dutch railway organization ProRail. Wind velocities occurring due to the passage of the train are analyzed for three zones: start, center and end of the platform (Fig. 9a).

\subsection{Computational domain, grid, boundary conditions and other computational settings}

The models are created in full-scale dimensions. The computational domain for both case studies with passenger train and freight train is divided in two subdomains: a stationary subdomain including tunnel and platform, and a sliding subdomain including the train (Fig. 10). The wheel rotations are not considered. Meshing of the subdomains is performed in a similar manner to the validation study. The number of cells over the height and the width of the tunnel is 36 and 37, respectively, which results in $2.99 \cdot 10^{6}$ cells for the stationary subdomain, and, $1.60 \cdot 10^{6}$ cells and $1.18 \cdot 10^{6}$ cells for the moving subdomains with passenger and freight trains, respectively. The computational settings from the validation study (Table 1) are also used in these case studies. The calculation time steps are equal to $5.59 \cdot 10^{-4} \mathrm{~s}$ and $8.27 \cdot 10^{-4} \mathrm{~s}$ for the case with the passenger train and the freight train, respectively. The total number of time steps for each case is 16520 .

\subsection{Results}

\subsubsection{Wind velocities at the start and end of the platform}

Wind velocities are monitored at four positions (Fig. 11: WT4, WK4, WT148, WK148) at a height of $1.2 \mathrm{~m}$ above the platform and at the start and end of the platform, where the most critical conditions occur. The names of the positions indicate the type of the zone and the distance in meter from the start of the platform. So, WK4 and WT4 are the positions in the middle of the walking and waiting zones, respectively, situated at $4 \mathrm{~m}$ distance from the start of the platform. These critical positions have been determined by monitoring velocity contour-plots while the train is passing the platform and they indicate the location of the maximum wind velocities occurring at the platform at a height of $1.2 \mathrm{~m}$. The wind velocities at these positions are provided in Figure 12. The observations are described

\footnotetext{
${ }^{1}$ Verlengd InterRegio Materieel (in Dutch), two-story passenger train built by Bombardier Transportation

${ }^{2}$ Transnational Railway Applications with eXtreme fleXibility, brand name of locomotives built by Bombardier Transportation
} 
below, where compression and expansion waves are defined as waves created in front of (just before the nose) and behind the moving train (just after the tail), respectively (Fig.1).

The main observations for the passenger train (Fig. 12a) are described in four parts:

1. Before the nose of the train reaches the positions WK4 and WT4 at the start of the platform (t $=0.0$ to $1.7 \mathrm{~s}$ ), the wind velocities due to the compression wave do not exceed the threshold value for wind discomfort $(5 \mathrm{~m} / \mathrm{s})$. However, just after the passing of the train nose $(\mathrm{t} \sim 1.7$ to $2.3 \mathrm{~s}$ ), wind gusts larger than $5 \mathrm{~m} / \mathrm{s}$ and up to $6.4 \mathrm{~m} / \mathrm{s}$ occur at positions WK4 and WT4.

2. After the tail of the train has passed the positions WK4 and WT4, oscillations in the expansion wave cause the threshold value of $12 \mathrm{~m} / \mathrm{s}$ to be exceeded at these points ( $\mathrm{t} \sim 4.7$ to $5.5 \mathrm{~s} ; 5.8$ to $6.2 \mathrm{~s} ; 6.9$ to $7.2 \mathrm{~s}$ ).

3. At the end of the platform (WK148, WT148), the compression wave causes wind velocities that gradually increase up to slightly higher than the $5 \mathrm{~m} / \mathrm{s}$ threshold $(\mathrm{t} \sim 2.8$ to $5.2 \mathrm{~s})$. After the train nose has passed ( $\sim 5.8$ to $6.2 \mathrm{~s}$ ), strong wind gusts up to $17.5 \mathrm{~m} / \mathrm{s}$ occur in the walking zone (WK148). Moreover, this gust lasts more than $0.5 \mathrm{~s}$ and has an acceleration more than $0.43 \mathrm{~m} / \mathrm{s}^{2}$ that can cause balance problems for waiting passengers.

4. After the tail of the train has passed the positions WK148 and WT148, wind velocities shortly exceeding the $12 \mathrm{~m} / \mathrm{s}$ threshold occur in the waiting zone $(\mathrm{t} \sim 8.3 \mathrm{~s})$.

The main observations for the freight train (Fig. 12b) are also described in four parts:

1. Before the nose of the train reaches the positions WK4 and WT4 at the start of the platform (t $<2.4 \mathrm{~s}$ ), wind velocities caused due to the compression wave are mostly below the $5 \mathrm{~m} / \mathrm{s}$ threshold. When the train nose reaches the monitoring points $(t \sim 2.4 \mathrm{~s})$, wind speed higher than $5 \mathrm{~m} / \mathrm{s}$ occurs. When the train nose has passed the monitoring points, also values higher than $5 \mathrm{~m} / \mathrm{s}$ occur, and they even exceed $12 \mathrm{~m} / \mathrm{s}$ - albeit for less than $0.5 \mathrm{~s}-$ in the walking zone $(\mathrm{t} \sim 3.1 \mathrm{~s})$.

2. After the tail of the train has passed the positions WK4 and WT4, wind speed exceeding the $12 \mathrm{~m} / \mathrm{s}$ threshold at the start of platform ( $\mathrm{t} \sim 6.8 \mathrm{~s}$ ) occurs due to the expansion wave. However, it lasts less than $0.5 \mathrm{~s}$ and it can be concluded than no dangerous gusts in the walking and waiting zones at the start of the platform are caused by the passing freight train.

3. At the end of the platform (WK148, WT148) wind velocities due to the compression wave only exceed the discomfort threshold $(t=3.5$ to $7.4 \mathrm{~s})$. After the nose of the train has passed the positions WK148 and WT148, wind velocities exceeding the $5 \mathrm{~m} / \mathrm{s}$ threshold occur in the waiting and walking zones ( $\mathrm{t} \sim 8.2$ to $9.3 \mathrm{~s}$ ).

4. After the tail of the train has passed the positions WK148 and WT148, wind velocities exceeding the $5 \mathrm{~m} / \mathrm{s}$ threshold briefly occur in the waiting zone $(\mathrm{t} \sim 12.3 \mathrm{~s})$ caused by the expansion wave.

Note that peak slipstream velocities $U_{\max }$ normalized by the train speed $\left(U_{\mathrm{P}}, \mathrm{U}_{\mathrm{F}}\right)$ in the near wake of the freight train $\left(\mathrm{U}_{\max } / \mathrm{U}_{\mathrm{F}}=0.53\right)$ are higher than for the passenger train $\left(\mathrm{U}_{\max } / \mathrm{U}_{\mathrm{P}}=0.45\right)$. This can be caused mainly by the difference in train cross-sections, nose and tail shapes, and the flow induced in the gaps between the carriages of the freight train.

To explain the differences of the induced flow between the two different train types, the next subsection will focus more in detail on the flow patterns.

\subsubsection{Contour plots of instantaneous wind speed at start of the platform}

Some contour plots of instantaneous wind speed induced at the start of the platform $(1.2 \mathrm{~m}$ above the platform) are provided here for the passenger and the freight trains (Fig. 13). In this figure, the discomfort threshold value $(5 \mathrm{~m} / \mathrm{s})$ and the danger threshold value $(12 \mathrm{~m} / \mathrm{s})$ are indicated in the colorbar: $0.13 \mathrm{U}$ and $0.31 \mathrm{U}$ for the passenger train, and $0.18 \mathrm{U}$ and $0.43 \mathrm{U}$ for the freight train, where $\mathrm{U}$ is the train speed. 
Fig. 13a-b shows that, for the passenger train, wind velocities exceeding the $5 \mathrm{~m} / \mathrm{s}$ threshold occur at the start of the platform along the train side just after the nose of the train has passed the measurement points WT4 and WK4. Oscillations in the expansion wave cause wind gusts exceeding the $12 \mathrm{~m} / \mathrm{s}$ threshold (Fig. 13d) as the wake behind the train is leaned to the platform due to the sudden change in tunnel cross-section and a difference in pressures at the platform and behind the train.

Fig. $13 \mathrm{f}$ shows that, for the freight train, wind velocities exceeding the $12 \mathrm{~m} / \mathrm{s}$ threshold occur at the start of the platform after the locomotive of the freight train has passed the measurement point. This can be due to rapid growth of boundary layer near the nose of the train (Fig. 13e) and the complex flow caused by the gap between the locomotive and the first carriage (Fig. 13f). As in the case with the passenger train, the leaned wake of the freight train causes wind speed exceeding $12 \mathrm{~m} / \mathrm{s}$ at the start of the platform (Fig. 13h).

\subsubsection{Contour plots of instantaneous wind speed at end of the platform}

Wind gusts reaching almost $18 \mathrm{~m} / \mathrm{s}$ occur at the end of the platform when the nose of the passenger train has passed the platform end due to a pressure wave created by the suddenly increased blockage ratio when the train enters the end part of the tunnel without platform (Fig. 14a-b). Oscillations in this pressure wave result in wind gusts reaching the $12 \mathrm{~m} / \mathrm{s}$ threshold in the walking and waiting zones at the end of the platform (Fig. 14b-d).

Despite the lower blockage ratio and lower running speed of the freight train, the compression wave of the freight train $(\mathrm{t}<7.5 \mathrm{~s})$ causes higher peak velocities $\mathrm{U}_{\max }$ normalized by the train speed in the walking and waiting zones at the end of the platform compared to the passenger train (Fig. 12): $\mathrm{U}_{\max } / \mathrm{U}_{\mathrm{F}}=0.26, \mathrm{U}_{\max } / \mathrm{U}_{\mathrm{P}}=0.17$. This can be caused by the less aerodynamic shape of the freight train. Note that for the freight train, wind velocities induced by the compression wave (Fig. 14e) and along the train side at the measurement positions at the end of the platform (Fig. 14f) are generally higher than those of the expansion wave (Fig. 14g-h) except for two short gusts at $\mathrm{t} \sim 8.3$ and $8.7 \mathrm{~s}$ (Fig. 12b).

\subsubsection{Contour plots of instantaneous wind speed along the platform}

While trains are passing the platform (Fig. 15) no significant oscillations in direction to the platform occur in the near wake resulting in absence of strong wind gusts at the platform in walking and waiting zones. As mentioned in section 4.3.1, slipstream velocities normalized by the train speed in the near wake for the freight train are higher than for the passenger train (Fig. 15b: large red region behind the freight train). This is caused by difference in cross-sections and tail shapes of the two trains. In addition, flow separation for the freight train occurs at the top edge of the last carriage, at the height of the train (Fig. 15d), while the wake behind the passenger train is more concentrated towards the ground surface due to the smoother tail shape (Fig. 15c). This feature of the near wake can contribute to higher induced wind speed ratios on the platform, but mainly near the start and end of the platform where the blockage ratio suddenly changes.

\section{Discussion}

This study shows the possibility to apply Large Eddy Simulation to analyze the wind flow induced at an underground railroad platform by a passing train. The computational model is validated by experimental data after which it is applied for two case studies. The occurring wind velocities on this platform are compared with threshold values for wind comfort and wind danger for pedestrians. The threshold value for wind discomfort $(5 \mathrm{~m} / \mathrm{s})$ however has been derived for natural wind conditions (outdoor) and is a mean value. Its applicability to gust winds experienced by passengers on railway platforms is assumed in the present study, but requires further exploration. Also, the threshold wind speed for wind danger $(12 \mathrm{~m} / \mathrm{s})$ is chosen based on experimental results for sudden sharp-edged gust. Als here the applicability for passengers on platforms requires further study. It should be noted that the European Union states the threshold of $15.5 \mathrm{~m} / \mathrm{s}$ (EU, 2014) for mean wind speeds induced by the 
train on an open-air platform. Also this threshold does not take into account gust effects, and its applicability for underground platforms should be further investigated.

The freight train considered in the present study is a fully loaded train with no gaps between containers, although it has gaps between the carriages. In addition, this train is rather short. The effects observed in the present study due to gaps between the carriages are expected to be amplified for notfully loaded trains. Furthermore, in case of longer trains, thicker boundary layers are expected compared to those of the train in the present study.

The present study only focused on velocity magnitudes at a given height. Future work might focus on vertical variations of wind gusts, which might cause overturning moments on a passenger.

In addition to the above-mentioned issues, future studies can focus on:

- refining the grid near the train surface to more accurately resolve the boundary layers at the moving train;

- investigating thoroughly the influence of train speed, train shape, train length and blockage ratio on normalized peak velocities occurring at the platform;

- elaborating comprehensive research criteria for wind discomfort and wind danger at the platform.

\section{Conclusions}

This study evaluated the effect of passing trains on the wind conditions induced inside an underground tunnel and at a passenger platform by means of Large-Eddy simulations (LES). The computational model was validated by experimental data for a reduced-scale train running through a tunnel. Two case studies were performed, for a passenger train and a freight train, where the dimensions of the tunnel and the platform were chosen from the Dutch design requirements for railroad tunnels and platforms. The results of the study showed that passengers standing on a platform can experience strong wind effects when passenger trains or freight trains are passing at speeds of 140 and $100 \mathrm{~km} / \mathrm{h}$, respectively. These effects might give rise to wind discomfort or even wind danger, and should be taken into account in the design of railway tunnels and platforms and in safety regulations. To evaluate potential wind discomfort and potential wind danger in this study, a wind speed of $5 \mathrm{~m} / \mathrm{s}$ was taken as the threshold value for wind discomfort, and the combination of values of gust wind equal to $12 \mathrm{~m} / \mathrm{s}$, its duration of $0.5 \mathrm{~s}$ and acceleration of $0.43 \mathrm{~m} / \mathrm{s}^{2}$ were used as threshold for wind danger. The following conclusions are made based on this study:

- The validation study shows a good agreement between numerical results and experiments. However, velocities inside the tunnel due to compression and expansion waves caused by the moving train are slightly underestimated.

- Exceedance of the wind discomfort threshold (wind speed of $5 \mathrm{~m} / \mathrm{s}$ ) occurs at the platform within the waiting and walking zones for both the passenger and freight train passing the platform.

- Short dangerous wind gusts (wind speed $>12 \mathrm{~m} / \mathrm{s}$, duration of $0.5 \mathrm{~s}$ and acceleration of 0.43 $\mathrm{m} / \mathrm{s}^{2}$ ) occur at the start and the end of the underground platform after the passenger train has passed the platform at a speed of $140 \mathrm{~km} / \mathrm{h}$. No dangerous wind gusts occur at the platform when the freight train passes it at a speed of $100 \mathrm{~km} / \mathrm{h}$.

- Wind speed occurring at the platform caused by the passenger train is stronger than the ones caused by the freight train, which is a result of the higher train speed and the higher blockage ratio of the passenger train.

- Slipstream velocities in the near wake normalized by the train speed are higher for the freight train than for the passenger train due to the less aerodynamic shape of the freight train and caused by differences in flow separation at the end of the train. Moreover, flow induced in the gaps between the carriages can enhance wind gusts and contribute to unfavorable wind effects on the platform. 


\section{Acknowledgements}

The authors gratefully acknowledge Tim Gilbert (University of Birmingham) for kindly providing high-quality and detailed measurement data from the TRAIN Rig of the University of Birmingham in Derby.

\section{References}

ANSYS Inc., 2009. ANSYS Fluent 12.0. User's Guide, ANSYS Inc.

Baker, C., Jordan, S., Gilbert, T., Quinn, A., Sterling, M., Johnson, T., and Lane, J., 2012. Transient aerodynamic pressures and forces on trackside and overhead structures due to passing trains. Part 1 Model scale experiments; Part 2 Standards applications. Proc. Inst. Mech. Eng., Part F: J. Rail Rapid Transit, p. 1-34.

Baker, C..J., 2007. Wind engineering - Past, present and future. Journal of Wind Engineering and Industrial Aerodynamics 95(9-11), 843-870.

Baker, C.J., 2010. The flow around high speed trains. J. Wind Eng. Ind. Aerodyn., 98: 277-298.

Baker, C.J., Sterling, M., Figura-Hardy, G., Johnson, T., Free, P., Munley, G., Bowman, I., Pope, C., and Gawthorpe, R., 2006. The effect of train slipstreams on passengers and trackside workers. Proceedings of the 7th World Congress on Railway Research, pp. 8. Montreal, Canada, 4-8 June 2006.

Baron, A., Mossi, M., and Sibilla, S., 2001. The alleviation of the aerodynamic drag and wave effects of high-speed trains in very long tunnels. J. Wind Eng. Ind. Aerodyn., 89: 365-401.

Blocken, B, Janssen, W.D., and van Hooff, T., 2012. CFD simulation for pedestrian wind comfort and wind safety in urban areas: General decision framework and case study for the Eindhoven University campus. Environ. Model. Softw., 30: 15-34.

Blocken, B. and Gualtieri, C. 2012. Ten iterative steps for model development and evaluation applied to Computational Fluid Dynamics for Environmental Fluid Mechanics. Environ. Model. Softw., 33: 1-22.

Blocken, B. and Stathopoulos, T. 2013. Editorial to virtual special issue: CFD simulation of pedestrian-level wind conditions around buildings: past achievements and prospects. J. Wind Eng. Ind. Aerodyn., 121: 138-145.

Blocken, B., 2014. 50 years of Computational Wind Engineering: Past, present and future. J. Wind Eng. Ind. Aerodyn.,129: 69-102.

Blocken, B., Stathopoulos, T., Carmeliet, J., and Hensen, J.L.M., 2011. Application of CFD in building performance simulation for the outdoor environment: an overview. J. Build. Perform. Simul., 4(2): 157-184.

Bopp, R. and Hagenah, B., 2009. Aerodynamics, ventilation and tunnel safety for high speed rail tunnels. Workshop on Tunnels for High-Speed Railways, pp.21. Porto, Portugal, 1-2 October 2009.

Bottema, M., 1993. Wind climate and urban geometry. Proefschrift/ PhD Thesis, Eindhoven University of Technology. ISBN 90-386-0132-8.

Britter, R. and Schatzmann, M. (Eds.), 2007. Model Evaluation Guidance and Protocol Document COST Action 732. COST Office Brussels, ISBN 3-00-018312-4.

Casey, M., Wintergerste, T., 2000. Best Practice Guidelines, ERCOFTAC Special Interest Group on Quality and Trust in Industrial CFD, ERCOFTAC, Brussels.

De Graaf, B. and Van Weperen, W, 1997. The retention of balance: an exploratory study into the limits of acceleration the human body can withstand without losing equilibrium. Human Factors: J. Hum. Factors Ergon. Soc., 39(1): 111-118.

Eighinger, S., Sima, M., and Thiele, F., 2013. Numerical simulation of regional train in $30^{\circ}$ cross wind. International Workshop on Train Aerodynamics, pp.4. Birmingham, England, 8-10 April 2013.

EU, 2014. Commission Regulation (EU) No 1302/2014 of 18 November 2014 concerning a technical specification for interoperability relating to the 'rolling stock - locomotives and passenger 
rolling stock' subsystem of the rail system in the European Union. Regulation. Official Journal of the European Union, L 356, 228-394.

Franke, J., Hellsten, A., Schlünzen, H., and Carissimo, B. 2011. The COST 732 best practice guideline for CFD simulation of flows in the urban environment - A summary. Int. J. Environ. Pollut., 44(1-4): 419-427.

Franke, J., Hellsten, A., Schlünzen, H., and Carissimo, B., 2007. Best Practice Guideline for the CFD Simulation of Flows in the Urban Environment. COST Action 732: Quality assurance and Improvement of Microscale Meteorological Models.

Franke, J., Hirsch, C., Jensen, A.G., Krüs, H.W., Schatzmann, M., Westbury, P.S., Miles, S.D., Wisse, J.A., and Wright, N.G., 2004. Recommendations on the use of CFD in wind engineering. Proceedings of the International Conference on Urban Wind Engineering and Building Aerodynamics. COST Action C14, Impact of Wind and Storm on City Life Built Environment, pp.11. Von Karman Institute, Sint-Genesius-Rode, Belgium, 5-7 May 2004.

Gil, N., Baker, C.J., and Roberts, C., 2008. The measurement of train slipstream characteristics using a rotating rail rig. BBAA VI International Colloquium on Bluff Body Aerodynamics \& Applications, pp.15. Milano, Italy, 20-24 July 2008.

Gilbert, T., Baker, C., and Quinn, A., 2013a. Aerodynamic pressures around high-speed trains: the transition from unconfined to enclosed spaces. Proc. Inst. Mech. Eng., Part F: J. Rail Rapid Transit, 227, 6: 609-622.

Gilbert, T., Baker, C., and Quinn, A., 2013b. Gusts caused by high-speed trains in confined spaces and tunnels. J. Wind Eng. Ind. Aerodyn., 121, 39-48.

Gilbert, T., Baker, C., Quinn, A., and Sterling, M., 2012. Aerodynamics of high-speed trains in confined spaces. Proceedings of the 7th International Colloquium on Bluff Body Aerodynamics and Applications, pp.10. Shanghai, China, 2-6 September 2012.

Hemida, H. and Baker, C., 2010. LES of the flow around a freight wagon subjected to crosswind. Comput. Fluids, 39(10): 1944-1956.

Hemida, H., Baker, C.J., and Gao, G., 2014. The calculation of train slipstreams using large-eddy simulation. Proc. Inst. Mech. Eng., Part F: J. Rail Rapid Transit, 228: 25-36.

Hemida, H., N. Gil, and Baker, C., 2010. LES of the slipstream of a rotating train, J. Fluids Eng., 132 (5), 051103-1-9.

Hieke, M., Gerbig, C., Tielkes, T., and Deeg, P., 2013. Mastering Micro-pressure wave effects: Countermeasures at the Katzenberg Tunnel and Introduction of a new German regulation to get micro-pressure wave emissions under control. International Workshop on Train Aerodynamics, pp.4. Birmingham, England, 8-10 April 2013.

Jordan, S., Johnson, T., Sterling, M., and Baker, C., 2008. Evaluating and modeling the response of an individual to a sudden change in wind speed. Build. Environ., 43: 1541-1534.

Lawson, T.V. and Penwarden, A.D., 1975. The Effects of Wind on People in the Vicinity of Buildings. Proceedings of the 4th International Conference on Wind Effects on Buildings and Structures, p. 605-622. Cambridge University Press, Heathrow.

Mochida, A. and Lun, I.Y.F. 2008. Prediction of wind environment and thermal comfort at pedestrian level in urban area. J. Wind Eng. Ind. Aerodyn., 96 (10-11): 1498-1527.

Moonen, P., Defraeye, T., Dorer, V., Blocken, B., and Carmeliet, J., 2012. Urban physics: effect of the microclimate on comfort, health and energy demand. Front. Archit. Res., 1(3): 197-228.

Novak, J., 2006. Single train passing through a tunnel. Proceedings of the European Conference on Computational Fluid Dynamics, pp 12. Egmond aan Zee, The Netherlands, 5-8 September 2006.

ProRail, 2012. OVS00067-v004. Ontwerpvoorschrift Perrons ProRail.

ProRail, 2014. Netverg2015 [pdf] Available at https://www.prorail.nl/sites/default/files/3327550v2b-netverklaring 2015 gemengde net.pdf [Accessed 28 August 2014].

Raghunathan, R.S., Kim, H.-D., and Setoguchi, T., 2002. Aerodynamics of high-speed railways train. Prog. Aerosp. Sci., 38: 469-514.

Ricco, P., Baron, A., and Molteni, P., 2007. Nature of pressure waves induced by a high-speed train travelling through a tunnel. J. Wind Eng. Ind. Aerodyn., 95: 781-808. 
Saussine, G., Allain, E., Ribourg, M., and Neel O., 2013. High speed in extreme conditions: ballast projection phenomenon. International Workshop on Train Aerodynamics, pp.4. Birmingham, England, 8-10 April 2013.

Sima M. and Venkatasalam N., 2013. Investigation of cross wind ground configurations for rail vehicles. International Workshop on Train Aerodynamics, pp.4. Birmingham, England, 8-10 April 2013.

Sima, M., Andreas Gurr, A., and Orellano, A., 2008. Validation of CFD for the flow under a train with 1:7 scale wind tunnel. BBAA VI International Colloquium on Bluff Body Aerodynamics \& Applications, pp.16. Milano, Italy, 20-24 July 2008.

Smagorinsky, J., 1963. General circulation experiments with the primitive equations. I. The basic experiment. Mon. Weather Rev., 91: 99-164.

Stathopoulos, T., 1997. Computational Wind Engineering: Past achievements and future challenges. J. Wind Eng. Ind. Aerodyn., 67-68: 509-532.

Stathopoulos, T., 2002. The numerical wind tunnel for industrial aerodynamics: real or virtual in the new millennium? Wind Struct., 5 (2-4): 193-208.

Stathopoulos, T., 2006. Pedestrian level winds and outdoor human comfort. J. Wind Eng. Ind. Aerodyn., 94(11): 769-780.

Sterling, M., Baker, C.J., Jordan, S.C., and Johnson, T., 2008. A study of the slipstreams of high-speed passenger trains and freight trains. Proc. Inst. Mech. Eng., Part F: J. Rail Rapid Transit, 222: 177.

Tominaga, Y., Mochida, A., Yoshie, R., Kataoka, H., Nozu, T., Yoshikawa, M., and Shirasawa, T., 2008. AIJ guidelines for practical applications of CFD to pedestrian wind environment around buildings. J. Wind Eng. Ind. Aerodyn. 96: 1749-1761.

van Hooff, T. and Blocken, B., 2010. Coupled urban wind flow and indoor natural ventilation modeling on a high-resolution grid: a case study for the Amsterdam ArenA stadium. Environmental Model. Softw., 25(1): 51-65.

Weise, M. and Sima, M., 2013. Towards a standard test procedure for aerodynamic loads on railway tracks. International Workshop on Train Aerodynamics, pp.4. Birmingham, England. 8-10 April 2013.

William-Louis, M. and Tournier, C., 2005. A wave signature based method for the prediction of pressure transients in railway tunnels. J. Wind Eng. Ind. Aerodyn., 93: 521-531.

Yoshie, R., Mochida, A., Tominaga, Y., Kataoka, H., Harimoto, K., Nozu, T., and Shirasawa, T., 2007. Cooperative project for CFD prediction of pedestrian wind environment in the Architectural Institute of Japan. J. Wind Eng. Ind. Aerodyn., 95(9-11): 1551-1578. 


\section{TABLES}

Table 1: Validation study: computational settings

\begin{tabular}{|l|l|}
\hline General settings & $\begin{array}{l}\text { Pressure-based with air of constant density (Mach number } \\
0.09 \text { ) }\end{array}$ \\
\hline Solver & $\begin{array}{l}\text { Large-Eddy Simulation with Smagorinsky-Lilly Subgrid Scale } \\
\text { Modeling (Smagorinsky 1963) }\end{array}$ \\
\hline Bodel & \\
\hline $\begin{array}{l}\text { Inlet and outlet } \\
\text { (moving subdomain) }\end{array}$ & $\begin{array}{l}\text { Velocity inlet with zero velocity and pressure outlet with zero } \\
\text { static pressure }\end{array}$ \\
\hline $\begin{array}{l}\text { Inlet and outlet } \\
\text { (stationary subdomain) }\end{array}$ & Pressure outlet with zero static pressure \\
\hline $\begin{array}{l}\text { Ground surface, tunnel } \\
\text { and train surfaces }\end{array}$ & $\begin{array}{l}\text { Wall, no-slip; y+ at the sidewalls of the train reaches maximum } \\
\text { value of 175, wall functions are employed if the grid is too } \\
\text { coarse to resolve the laminar sublayer }\end{array}$ \\
\hline Solution methods & \\
\hline $\begin{array}{l}\text { Pressure-velocity } \\
\text { coupling scheme }\end{array}$ & Fractional step \\
\hline Spatial discretization & \\
\hline Gradient & Least Squares Cell Based \\
\hline Pressure & $2^{\text {nd }}$ order \\
\hline Momentum & Bounded Central Differencing \\
\hline Transient formulation & $2^{\text {nd }}$ order Implicit, Non-Iterative Time Advancement (NITA) \\
\hline Cell zone conditions & Moving mesh (V = 32.0 m/s) for train subdomain \\
\hline Calculation time step & $3.44 \cdot 10^{-5} \mathrm{~s}$ \\
\hline Number of time steps & 12960 \\
\hline
\end{tabular}




\section{FIGURES}

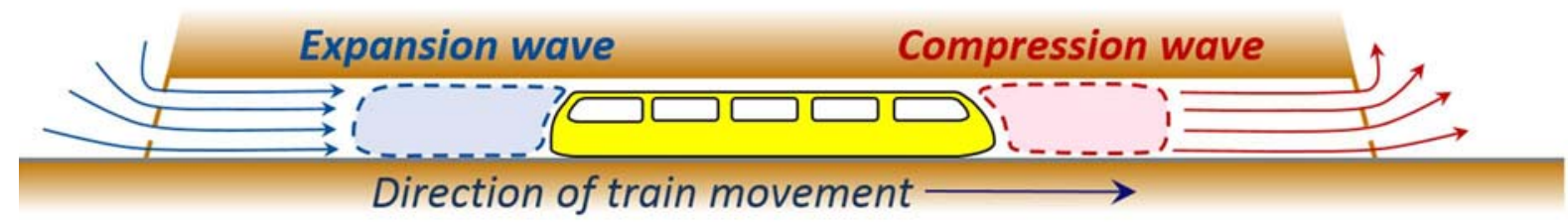

Figure 1: Wave generation by a train moving through a tunnel.

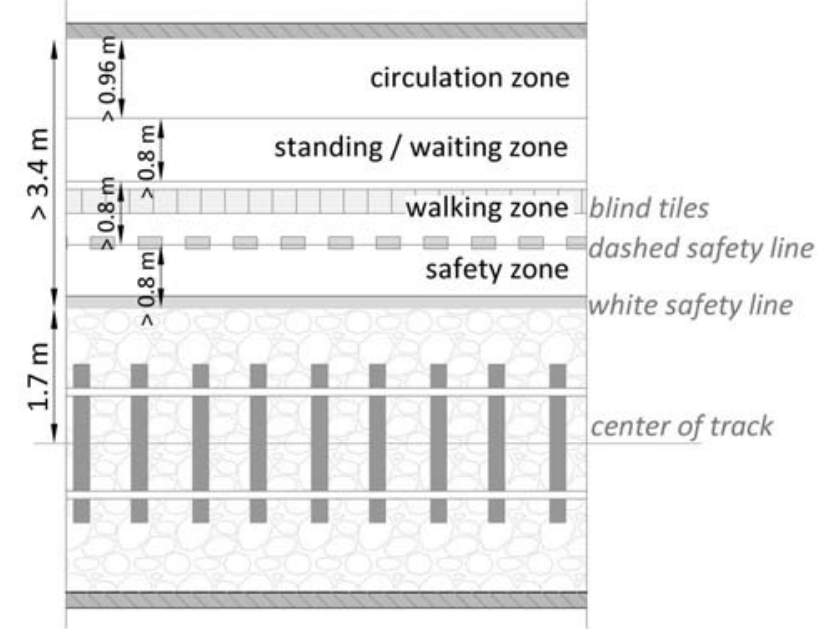

Figure 2: A train platform in The Netherlands divided into four zones (ProRail 2012).
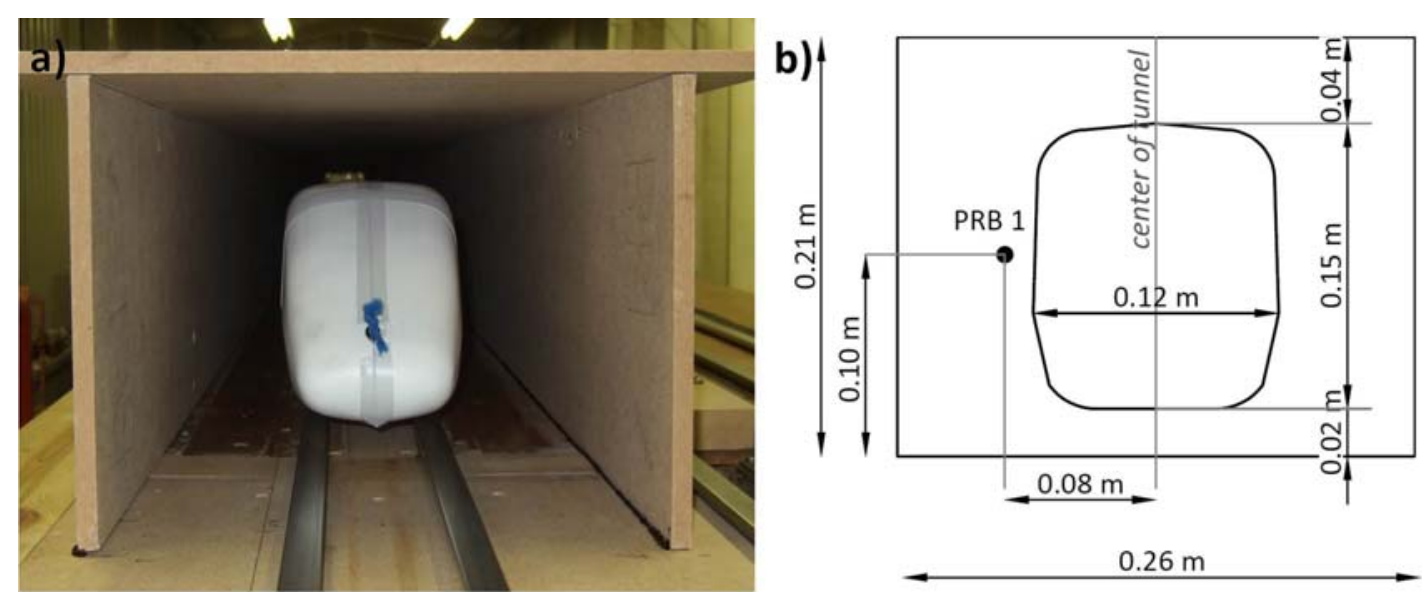

Figure 3: a) Tunnel and train model used in the experiments; b) Position of train and PRB1 inside the tunnel. 
a)
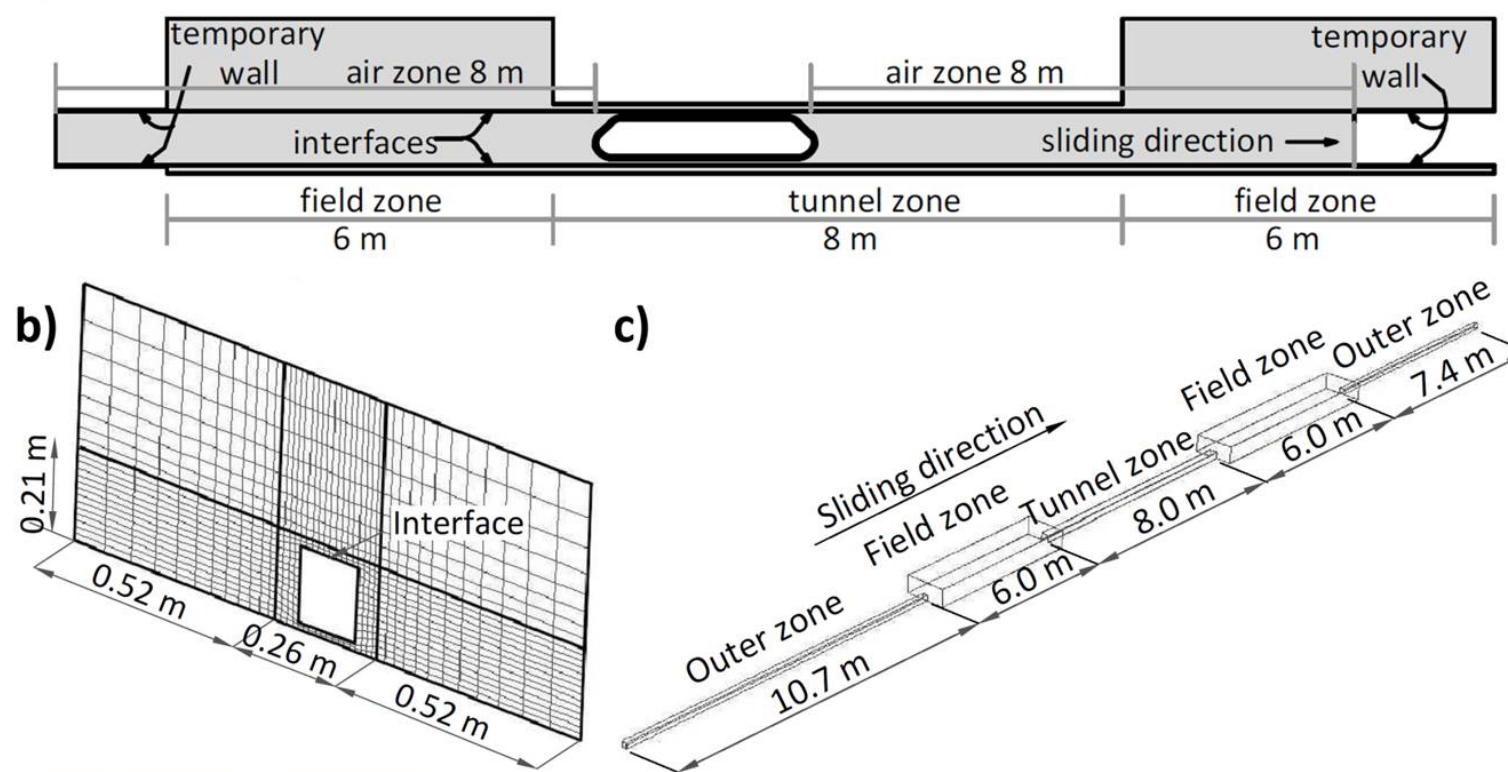

c)
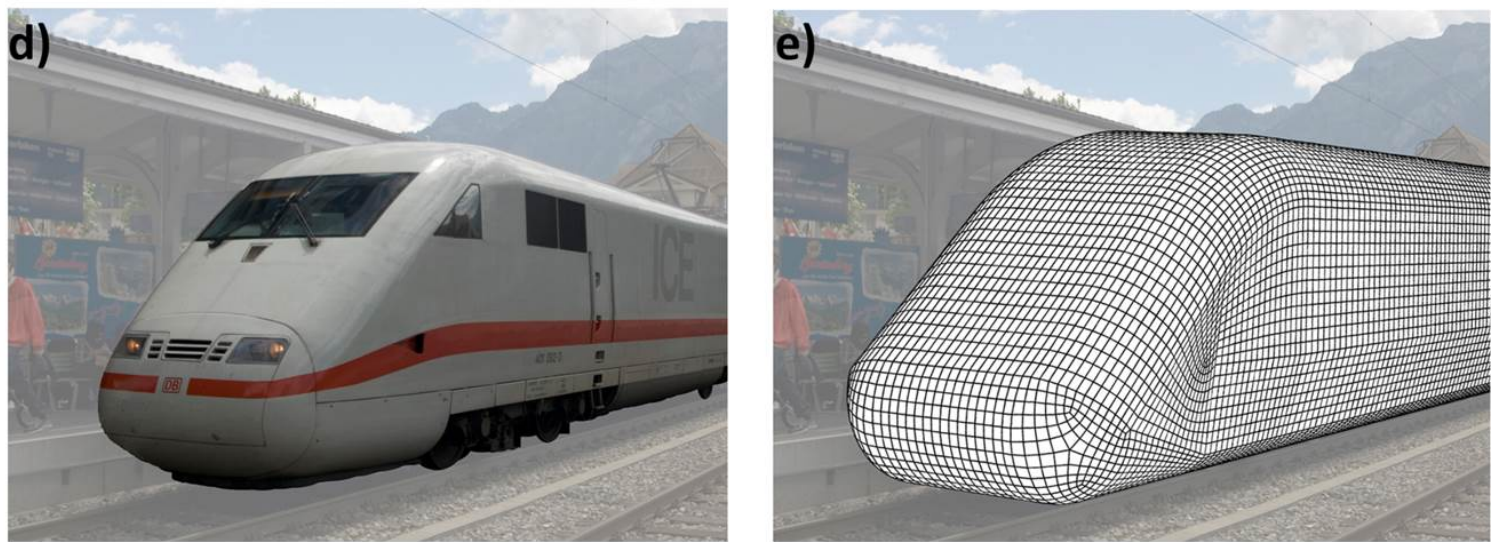

Figure 4: a) Overview of the computational domain showing stationary and sliding subdomains; b) Grid for the cross-section of the stationary subdomain; c) Overview of the stationary subdomain. Dimensions are in scale of 1:25; d) German ICE-2 train; e) Surface grid of the train. 


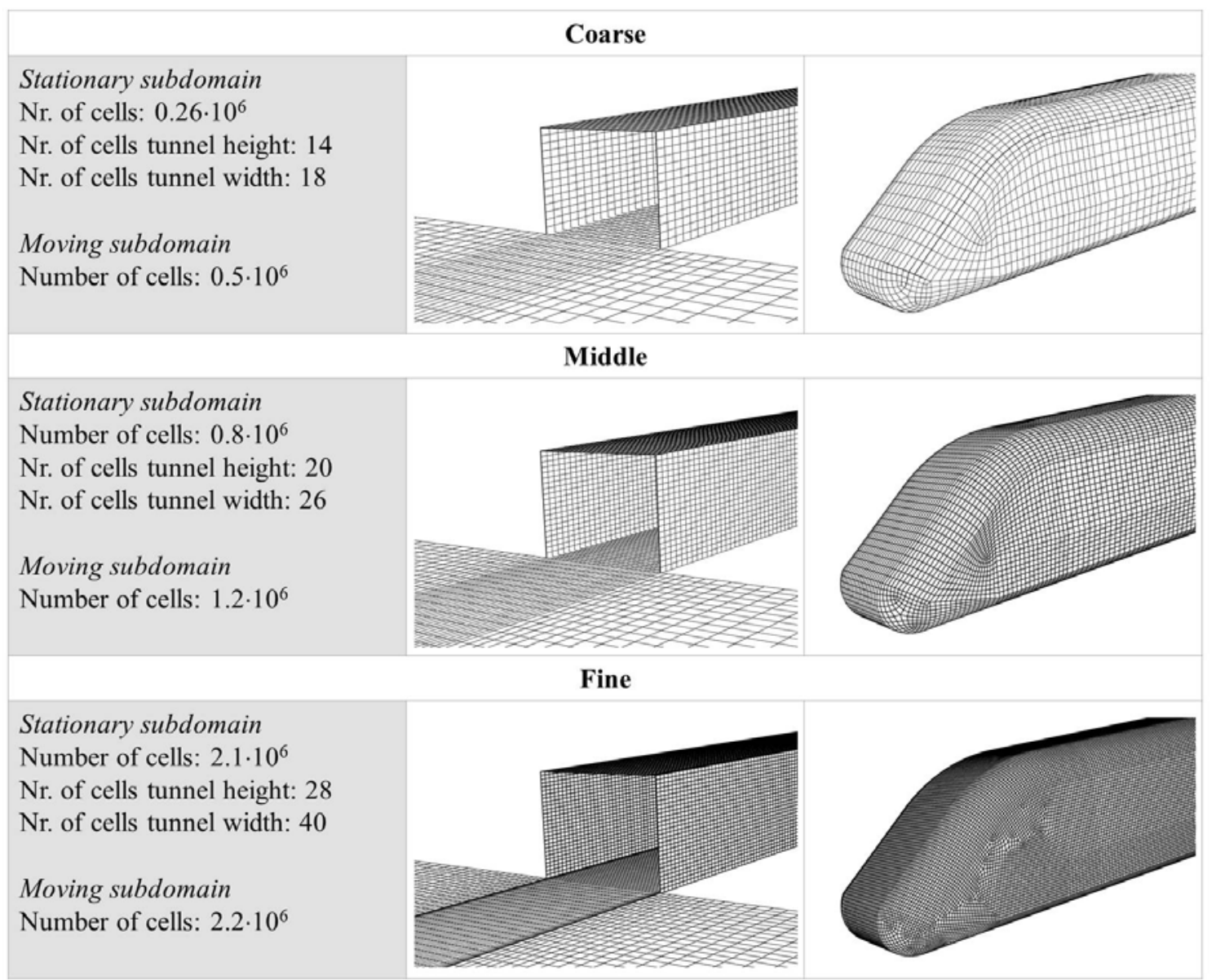

Figure 5: Overview of three grids for grid-sensitivity analysis.

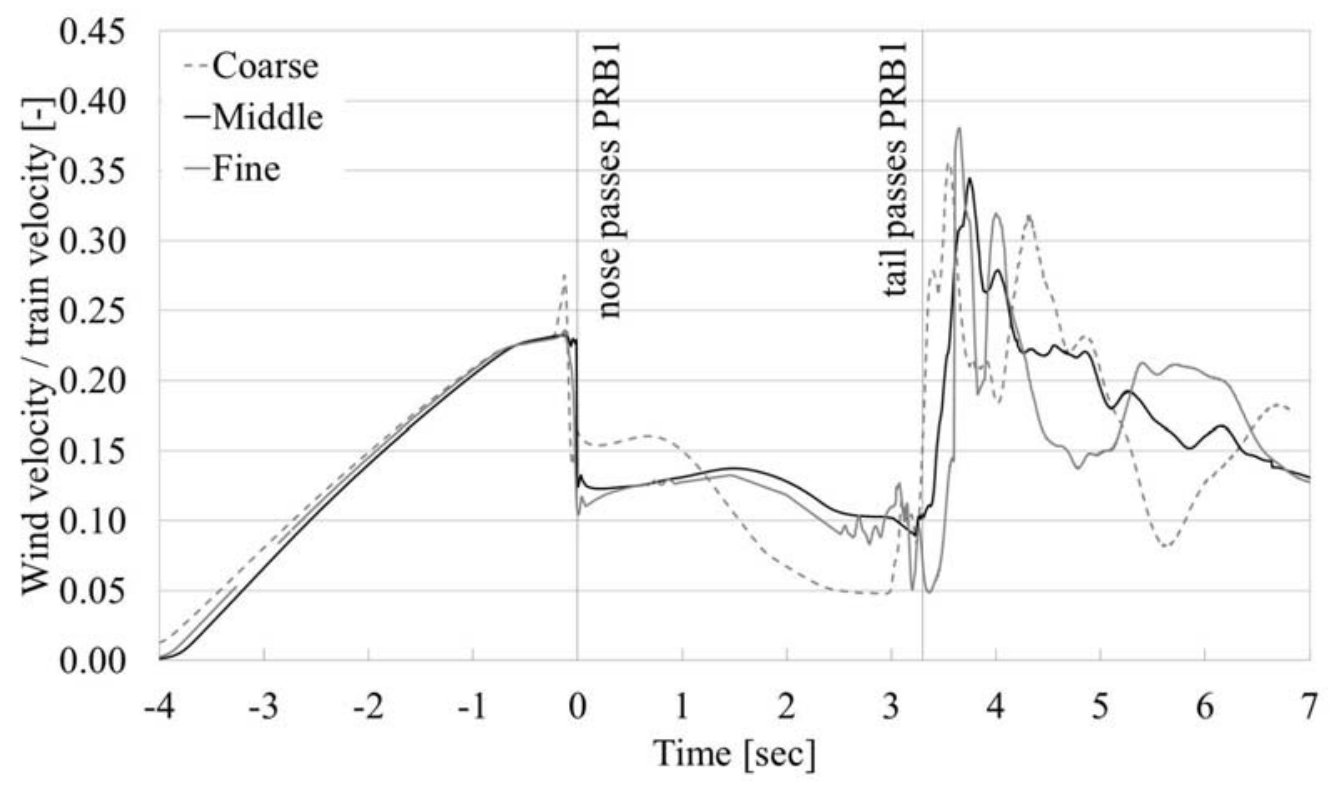

Figure 6: Normalized velocities at data point PRB1 obtained by CFD simulations with the three different grids. Note that the time on the horizontal axis is translated to equivalent fullscale value by multiplying it by 25 . 


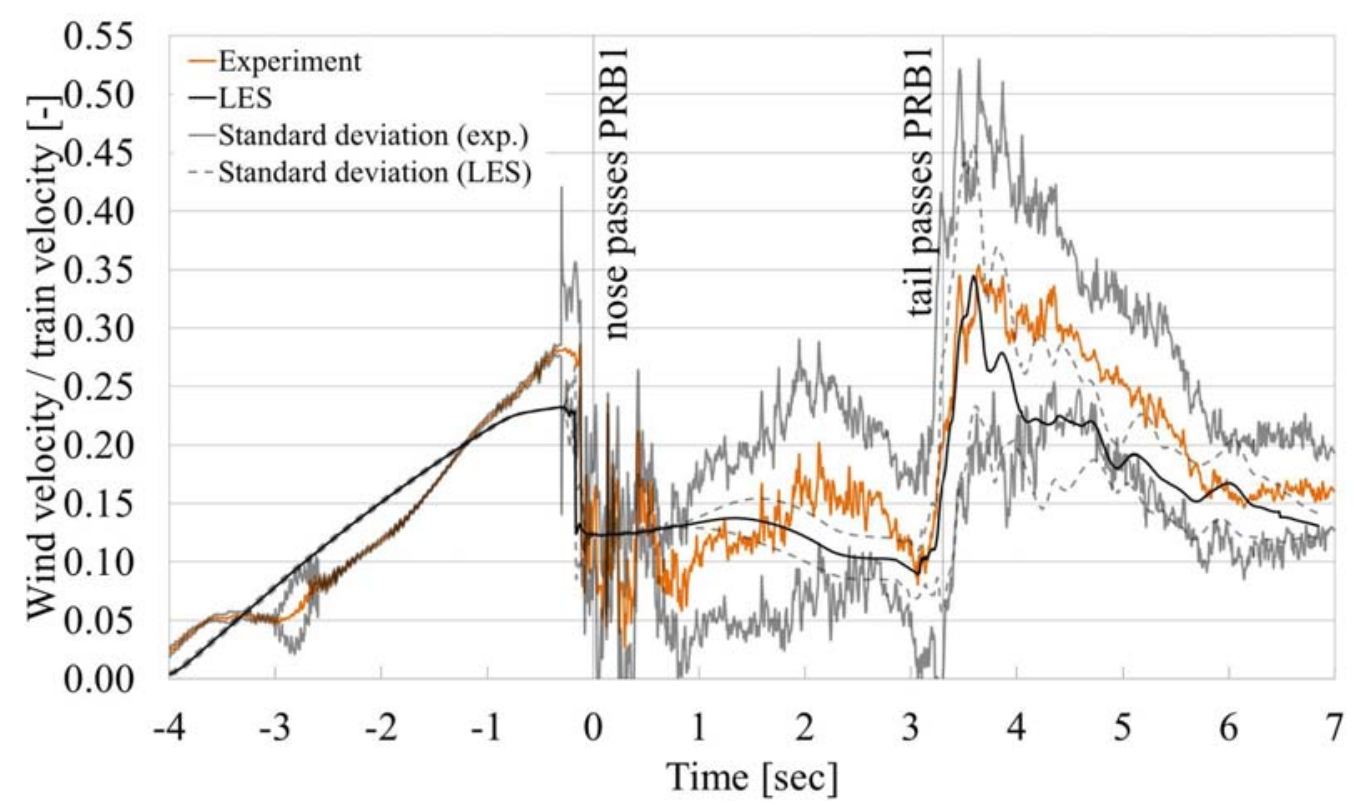

Figure 7: Normalized velocities at measurement point PRB1 obtained by experiments and numerical simulations. The nose of the train passes the measurement point at the time of $0.0 \mathrm{~s}$, while the tail of the train passes at $3.3 \mathrm{~s}$. Light grey lines represent standard deviation of the measurements (solid lines) and of the CFD simulations (dashed lines).
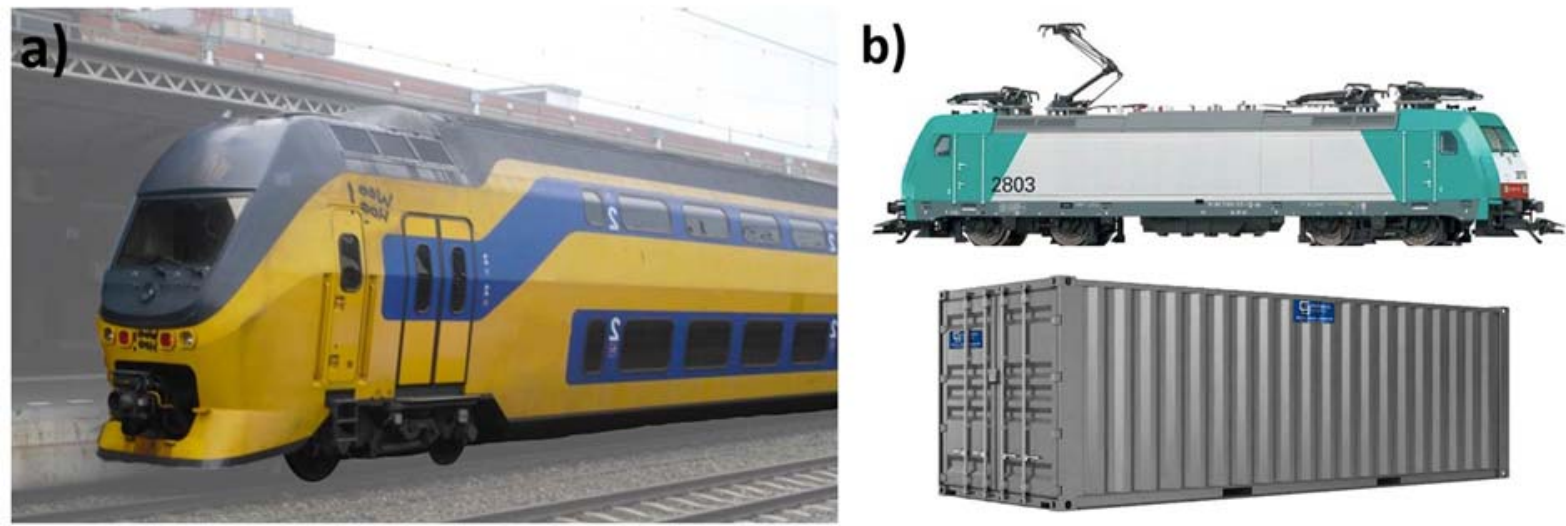

Figure 8: a) Passenger (VIRM) train $107.5 \mathrm{~m}$ long; b) Freight train $105.2 \mathrm{~m}$ long consisting of TRAXX 2803, locomotive and container. 


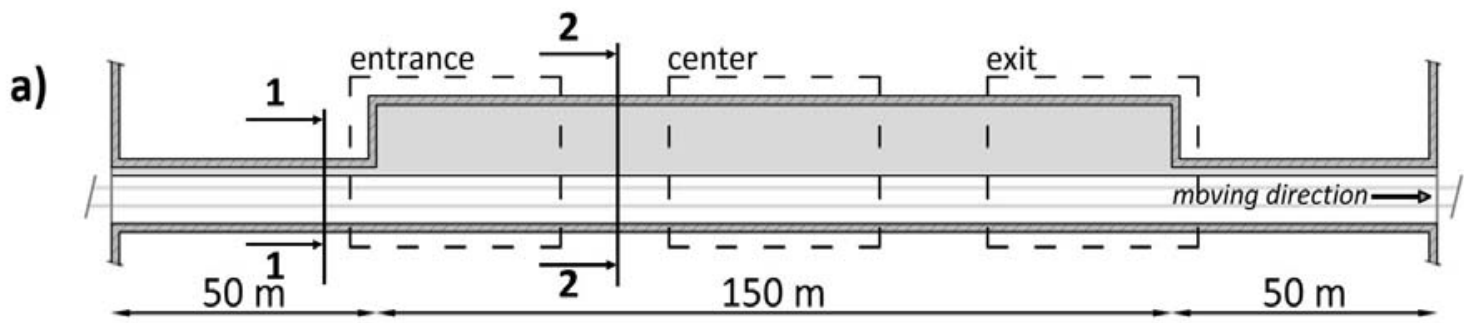

b)
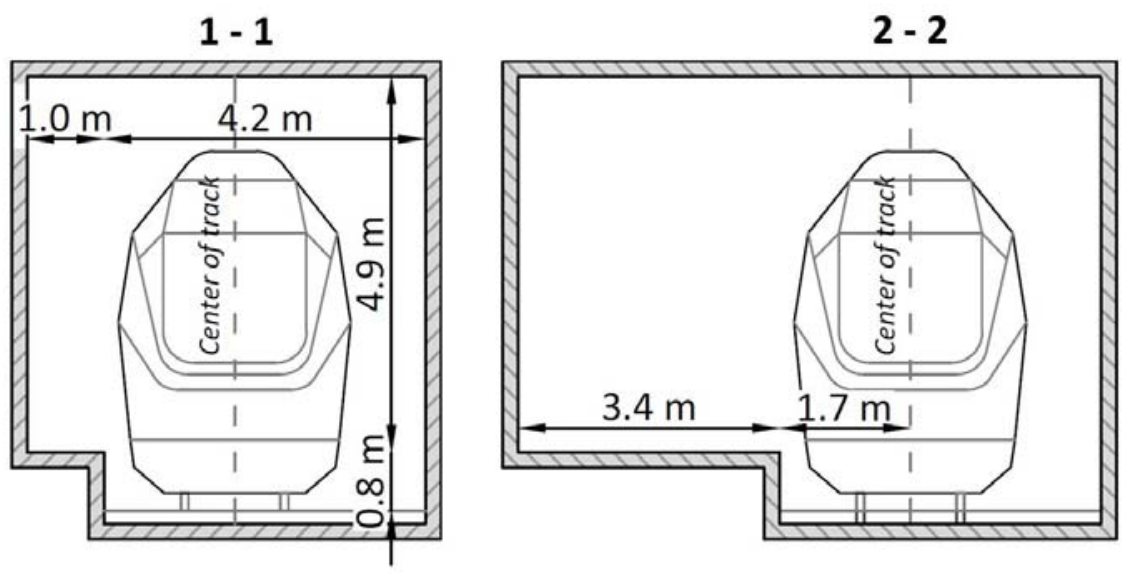

Figure 9: a) Top view of tunnel with platform; b) Vertical cross-sections through tunnel and platform.

a)

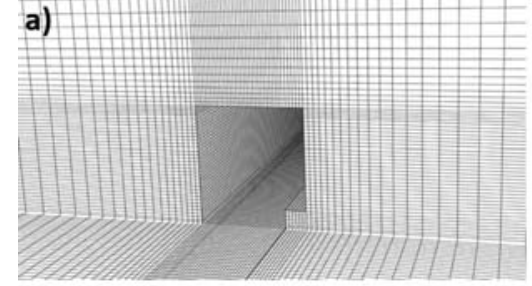

b)

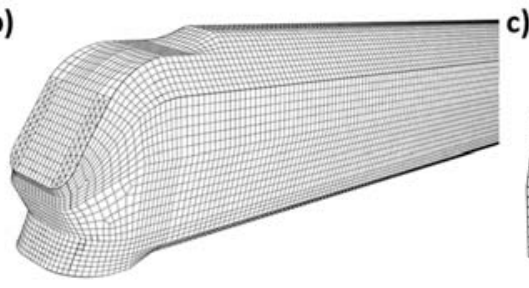

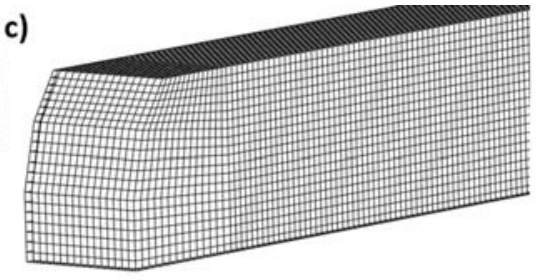

Figure 10: a) Part of grid of stationary subdomain; b) Part of surface grid of the intercity train VIRM; c) Part of surface grid of the freight train

a)

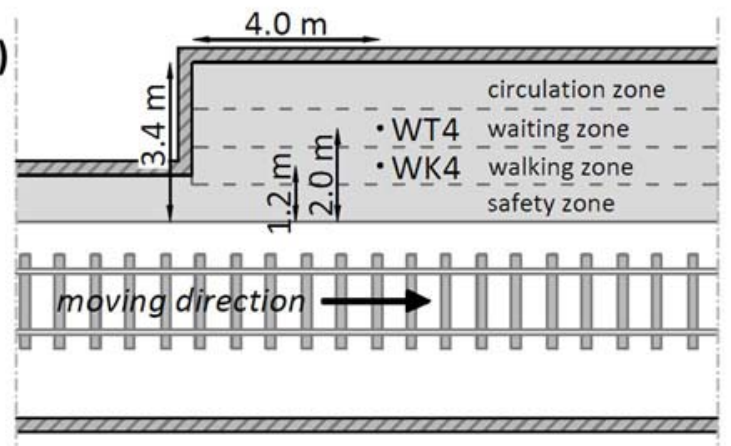

b)

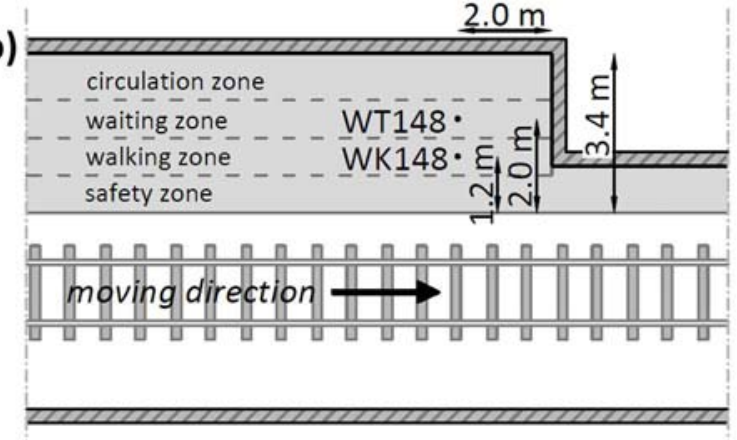

Figure 11: Top view on the underground platform and positions of monitoring points: a) start; b) end 

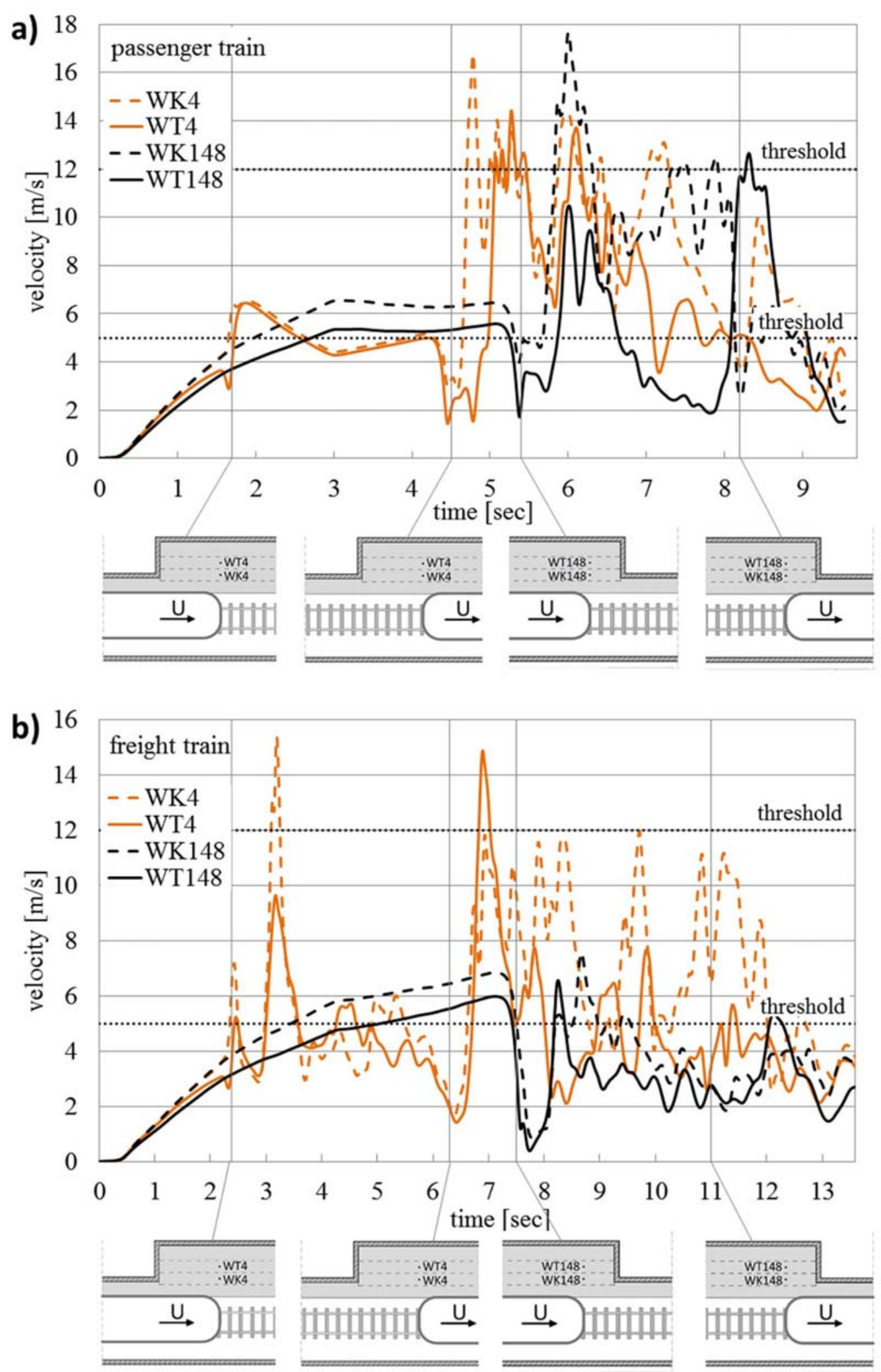

Figure 12: Computed velocities at $1.2 \mathrm{~m}$ above the platform for: a) the passenger train: at $1.7 \mathrm{~s}$ and $4.5 \mathrm{~s}-$ the nose and tail of the train, respectively, pass points at $4 \mathrm{~m} ;$ at $5.4 \mathrm{~s}$ and $8.2 \mathrm{~s}-$ the nose and tail of the train, respectively, pass points at $148 \mathrm{~m}$; b) the freight train: at $2.4 \mathrm{~s}$ and $6.3 \mathrm{~s}-$ the nose and tail of the train, respectively, pass points at $4 \mathrm{~m}$; at $7.5 \mathrm{~s}$ and $11.0 \mathrm{~s}-$ the nose and tail of the train, respectively, pass points at $148 \mathrm{~m}$ ). 


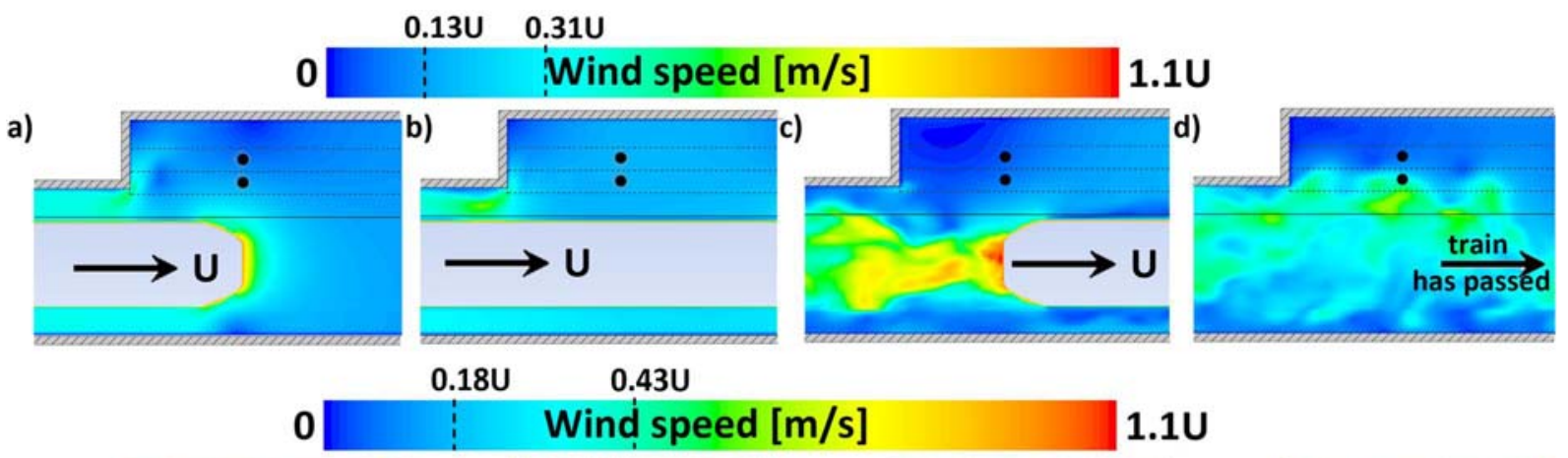

e)
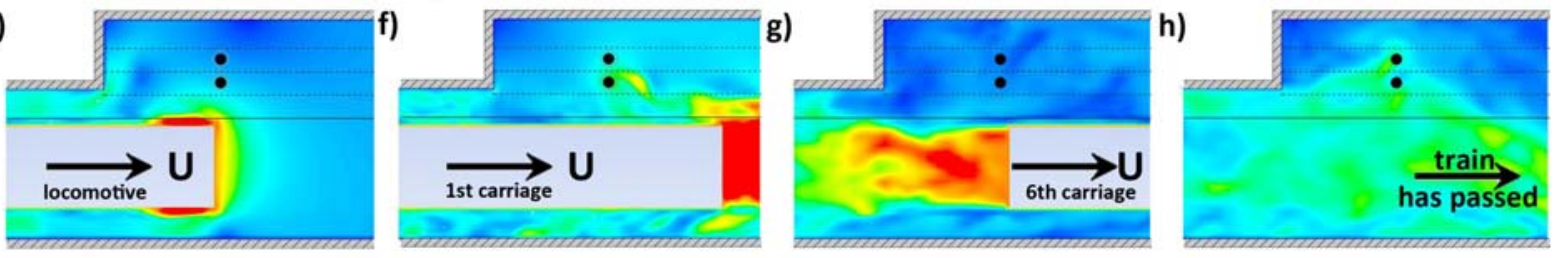

Figure 13: Contour plots of instantaneous wind speed at a height of $1.2 \mathrm{~m}$ above the platform at the start of the platform by: the passenger train at a) $t=1.7 \mathrm{~s}, \mathrm{~b}$ ) $\mathrm{t}=1.9 \mathrm{~s}, \mathrm{c}$ ) $\mathrm{t}=4.5 \mathrm{~s}$, and d) $\mathrm{t}=4.7 \mathrm{~s}$; train is moving with speed $\mathrm{U}=38.9 \mathrm{~m} / \mathrm{s}$; the freight train at e) $\mathrm{t}=2.4 \mathrm{~s}, \mathrm{f}$ ) $\mathrm{t}=3.1 \mathrm{~s}$, g) $t=6.3 \mathrm{~s}$, and $\mathrm{h}) \mathrm{t}=6.8 \mathrm{~s}$; train is moving with speed $\mathrm{U}=27.8 \mathrm{~m} / \mathrm{s}$
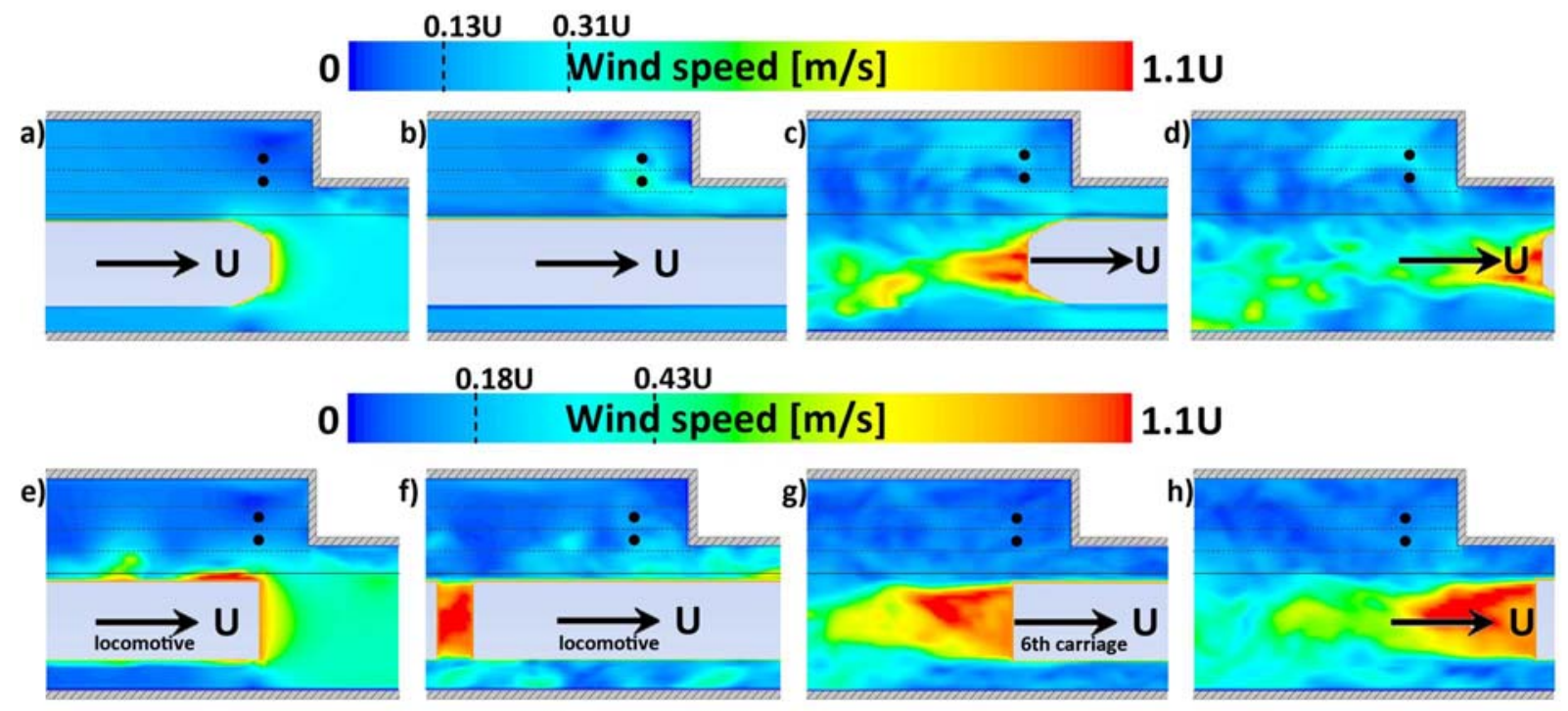

Figure 14: Contour plots of instantaneous wind speed at a height of $1.2 \mathrm{~m}$ above the platform at the end of the platform by: the passenger train at a) $t=5.4 \mathrm{~s}, \mathrm{~b}) \mathrm{t}=6.2 \mathrm{~s}, \mathrm{c}) \mathrm{t}=8.2 \mathrm{~s}$, and d) $\mathrm{t}$ $=8.4 \mathrm{~s}$; train is moving with speed $\mathrm{U}=38.9 \mathrm{~m} / \mathrm{s}$; the freight train at e) $\mathrm{t}=7.5 \mathrm{~s}, \mathrm{f}$ ) $\mathrm{t}=8.4 \mathrm{~s}, \mathrm{~g}$ ) $\mathrm{t}=11.0 \mathrm{~s}$, and $\mathrm{h}) \mathrm{t}=11.5 \mathrm{~s}$; train is moving with speed $\mathrm{U}=27.8 \mathrm{~m} / \mathrm{s}$. 


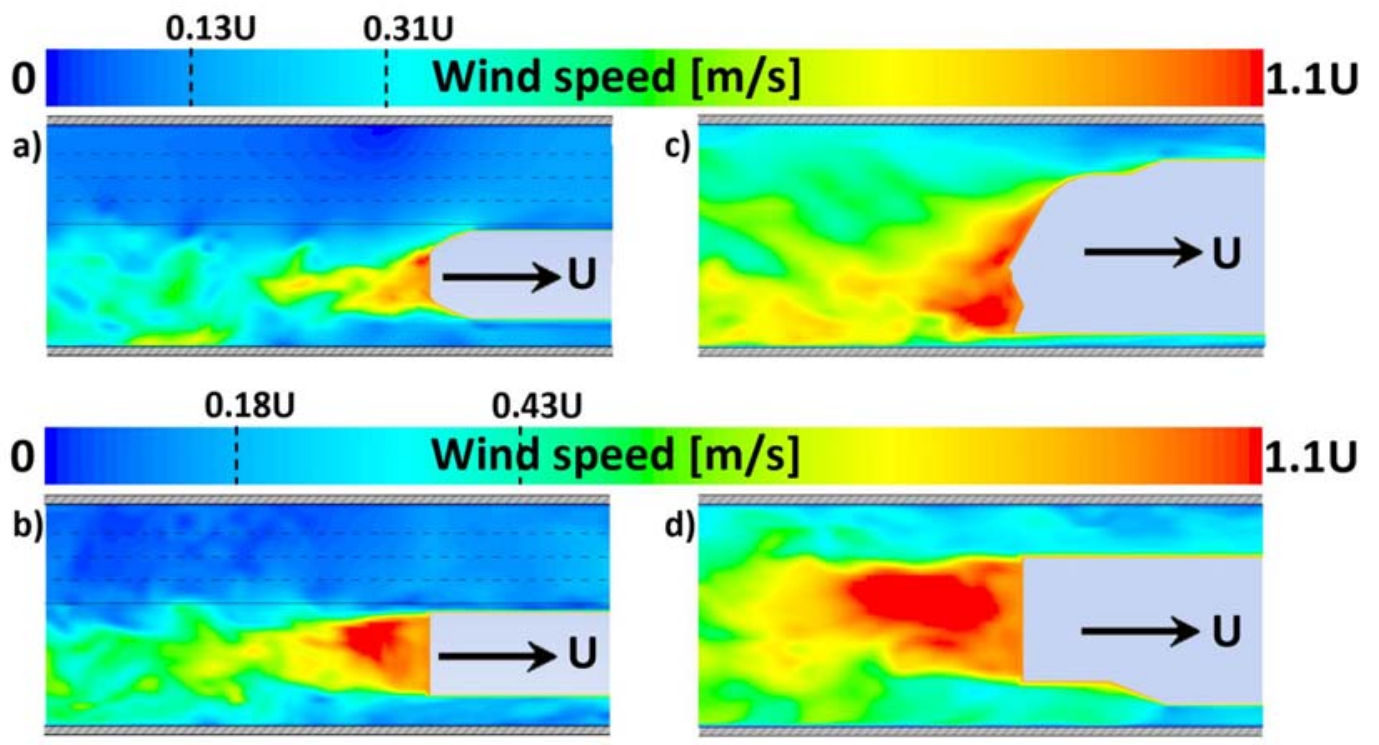

Figure 15: Contour plots of instantaneous wind speed by a), c) the passenger train $(U=38.9$ $\mathrm{m} / \mathrm{s})$ and $\mathrm{b}), \mathrm{d})$ the freight train $(\mathrm{U}=27.8 \mathrm{~m} / \mathrm{s})$. Horizontal contour plots $\mathrm{a})$ and $\mathrm{b})$ are taken at a height of $1.2 \mathrm{~m}$ above the platform, vertical contour plots $\mathrm{c}$ ) and d) are taken at the center of the train. 